\title{
"Night Hawks" Watching Over the City: Redeployment of Night Watchmen and the Politics of Public Space in Turkey
}

\author{
Bülent Batuman'(D) and Feyzan Erkip'
}

\begin{abstract}
Technological advances have enormously increased surveillance techniques in the last three decades. In this article, we scrutinize the re-instatement of bekçi, the traditional night watchmen patrolling the residential neighborhoods in Turkey, which was obsolete for decades. We analyze the re-emergence of the bekçi in relation to the dynamics of urbanization, and with a perspective of power and surveillance. Our discussion bridges the Foucauldian notion of "visibility," equating it with being subject to surveillance, and the Arendtian emphasis on "appearance" as the precondition for a claim to public space (hence, citizenship) in order the uncover the role of visibility within the mechanisms of power in public space. We argue that although the bekçi seems outmoded, especially within the context of ever-increasing advancement of surveillance technologies; its recent deployment in the public spaces of Turkish metropolises brings about new modes of politics of visibility parallel to the changing modality of the urban environment.
\end{abstract}

\section{Keywords}

Bekçi, watchmen, surveillance, visibility, public space

One summer evening around $10 \mathrm{PM}$, two middle-aged women left a restaurant and walked about 50 meters to be stopped by two young male officers. The restaurant where the women dined was on a street in an upper-class residential district of Ankara, full of eating and dining places. The officers were visibly younger than 30 years, had grey uniforms and badges on their chest indicating their post as bekçi, in capital letters. The bekçi, obsolete for decades, was the traditional night watchmen in Turkey, remembered as a nostalgic patriarchal figure watching over the neighborhood. It was controversially reinstated in 2017 in a very different form. When stopped and asked to show their IDs, the two women, reminiscing the old and friendly image of the bekçi from their childhood, lightheartedly asked the reason for being selected, as there were other people - mostly male - passing by. Instead of responding to the question, the young men explained that they were different from the old bekçi and now had the same authority with the police. They used their tablets to establish online connection with the police database and checked the two women's information in a very serious manner. Afterwards, they demanded to inspect the women's handbags, which was something even male police officers would refrain from doing in routine inspections.

'Bilkent University, Ankara, Turkey

\section{Corresponding Author:}

Bülent Batuman, Bilkent University, Inonu Bulvarı, Ankara 06800, Turkey.

Email: batuman@bilkent.edu.tr 
This incidence was illustrative of the controversy surrounding the reinstatement of the bekçi. For some, it has a nostalgic touch and creates a sense of security in the neighborhood; for others, it represents a threat to their lifestyles - especially under the conservative agenda of the Islamist Justice and Development Party ruling the country for 16 years. Indeed, newspaper articles reporting cases of bekçi intervening in the nightlife of Istanbul and Ankara are worrisome as they indicate single women and LGBT individuals as prime suspects.

In this article, we analyze the re-emergence of the bekçi in relation to the urban condition in Turkish cities and with a perspective of power and surveillance. We argue that the old bekçi was a component of the urban condition of the Turkish cities growing under pressure of rural to urban migration physically marked by the ever-growing squatter areas. We see their dissolution as an indication of a changing modality of the urban environment. Thus, we scrutinize the current urban condition to uncover the role the new bekçi could play in the current moment. It is crucial to note that the return to this seemingly obsolete institution is based on the bodily presence of the watchmen. Here, in contrast to the techniques of surveillance excelled in making power invisible in the eyes of the subjects, the appearance of the bekçi not only in neighborhoods but also in public spaces complicates the disciplinary mechanisms of power. Thus, the visibility and empowerment of the new bekçi go hand in hand. Therefore, the question we seek to investigate is how the appearance of the bekçi (a seemingly obsolete security mechanism) functions within the contemporary urban condition increasingly relying on high-tech surveillance for security. We explore this question with particular attention to the new regime of visibility it generates regarding the social control of public space.

Our inquiry is based on a review of legal regulations and recent newspaper articles as well as in-depth interviews with police officers from various administrative levels and the Police Academy. ${ }^{1}$ We aimed to obtain information on the reasons of bekçi revival, their recruitment and training processes and expected developments related to bekçi institution. We also studied exam questions prepared for the recruitment of new bekçi to explore any particular choice of recruits.

\section{Visibility and Control in Public Space}

Technological advances have enormously increased surveillance techniques in the last three decades (Lyon, 2007). New information technologies made it possible to widen the reach and capability of monitoring (Leman-Langlois, 2019). Video surveillance has particularly become an indispensable tool in controlling the contemporary cities (Fussy and Coaffee, 2012). Pointing out the decreasing crime rates, Tulumello (2015) defines fear of crime as a common myth in the Western world, and claims that fortification and privatization of public spaces have created "fearscapes," reproducing differences along local landscapes. In fact, fear of crime has served as an excuse for increasing surveillance and control, which was further prompted by the escalating fear of terrorism, especially after 9/11 (Webb, 2007). The scholarship on the impact of surveillance systems in relation to the politics of public space has largely relied on Foucault's pioneering work on disciplinary society and the panopticon. According to him, the person under surveillance "is seen, but he does not see; he is the object of information, never a subject in communication" (Foucault, 1995/1977, p. 200). In stark contrast to Foucault, who thinks "visibility is a trap," Hannah Arendt (1998/1958, pp. 198-199) has famously defined public space as "the space of appearance," where people appear to each other simultaneously and "exist not merely like other living or inanimate things but make their appearance explicitly."

Therefore, public space is marked by the dialectic of visibility and appearance. The citizen is visible to the gaze of power, but their appearance in public space is also a claim to this very space. It has to be noted that neither visibility (in the sense to be subject to the gaze of power) nor appearance (to become a citizen by participation in public space) can simply be reduced to the components of a binary opposition (where the former is negative, and the latter is positive). In 
fact, these two modes of visual acknowledgment are interlinked. In his analysis on "microsocial" practices of young people in Brussels, de Backer (2018) calls attention to the role of visibility as a part of public processes of interaction and underlines that "being visible by appropriation or making visible through control are heavily intertwined" (p. 10). Departing from Arendt's view, Charlesworth (2009) shows how "presence" in the "space of appearance" is mediated by "value," and points out examples where in/visibility is closely related to exclusion (and even self-exclusion). In addition, the expanding role of technological surveillance brought about new issues such as "collateral visibility" (involuntary registration within the public record as a subject) (Newell, 2017), and inverse and reciprocal forms of surveillance (Koskela, 2004; Timan and Albrechtslund, 2018).

In this article, we will deploy the two concepts - visibility and appearance - to analyze the curious re-emergence of night watchmen (bekçi) in the public space in Turkey. Our focus is on its relation to the changing urban conditions and the politics of visuality that operates within the deployment of the bekçi. We will argue that the changing urban condition designates a new regime of visibility in public space articulating visibility/ invisibility and appearance/ disappearance of citizens as well as security forces.

\section{Bekçi in the Context of Turkish Urbanization}

The bekçi dates back to as early as the seventeenth-century Ottoman Empire (Aksungur, 2018). Its emergence is directly related to visibility; or rather lack of it, with the limited lighting of streets at nights. While this task was initially undertaken by neighbors, this later gave way to the employment of a watchman. The bekçi was employed collectively by the neighborhood mahalle. Mahalle is the Turkish equivalent of neighborhood but is also an administrative unit inherited from the Ottoman system. The Ottoman social structure based on faith-based segregation found its physical expression in the mahalle, which was initially controlled by the religious leader and later (with the nineteenth-century reforms) the muhtar as the head of the neighborhood (Karpat, 2002). Therefore, Ottoman mahalle was generally occupied by a homogeneous population of similar faith. The shared space of worship functioned as the focus of mahalle; this was the mosque in the case of Muslim neighborhoods.

In addition to night patrol, the bekçi also undertook several tasks within the daily life of the neighborhood such as relating the public announcements to the people, alarming the people in the case of a fire, announcing the time (generally by pounding the pavement with his staff), and even assisting the neighbors in their personal labors (such as carrying wood). As a result, the profile of the bekçi was preferred as middle-aged and friendly (since he would be expected to enter houses due to these secondary tasks) rather than young and virile as the primary task would require (Aksungur, 2018, pp. 103-104).

The Ottoman mahalle, as mentioned earlier, had a strong sense of identity, and this also reflected itself in the control of behaviors along common morals. Popular pressure was imposed via performances called mahalle baskınt: noisy and public raids on suspected houses (Boyar \& Fleet, 2010, p. 122). The case would usually be the sighting of an unrelated man in a woman's house. The bekçi played a key role in informing the men of the neighborhood and their organization (most of the time in the coffeehouse), and leading the raiding party with his lantern. This brief history of the Ottoman bekçi illustrates the origins of the prevailing traditional image of the patriarchal figure of the bekçi with a dual character: a friendly and reliable officer seen as a member of the community and an authority figure assuming the responsibility of preventing immoral behavior in the mahalle.

Although employed collectively by the neighborhood, the bekçi began to be viewed as the authority figure as an extension of the state in the nineteenth century. They were even charged with providing intelligence directly to the palace during the reign of Abdul Hamid II ( $\mathrm{r}$. 
1876-1909) (Levy, 2008). The establishment and gradual expansion of a police organization separate from the military and the emergence of municipalities in the second half of the nineteenth century transformed the bekçi as well. Now they were responsible to the municipality, which replaced their staff with whistles as official equipment (Aksungur, 2018, p. 113). The bekçi was institutionalized as a governmental organization - as assistants to the police - in 1914. They were provided with uniforms and were merged with market watchmen; which is significant in the officialization of the bekçi as well as its changing urban character.

Safety of market (place) was very important for the Ottoman state (Boyar \& Fleet, 2010, p. 170). Thus, the marketplace (çarşı) was policed by watchmen appointed by the shopkeepers (similar to the employment of the bekçi by the mahalle). Yet, these two physical spaces (the çarşı and the mahalle) and their policing were completely separated until the twentieth century. With the new regulations in 1914, the organization of the bekçi in relation to the municipality merged the hitherto separated policing of the mahalle and the market: they were labeled "çarşı ve mahalle bekçisi" (bekçi of marketplace and neighborhood). This merger represents the dissolution of the mahalle as a segregated urban unit and its recognition instead as an urban quarter not unlike the marketplace in the city center. Within this framework, the bekçi would assist the police, the primary force responsible for security in the city.

This organizational structure was taken over by the Turkish Republic following the foundation of the nation-state in 1923. Interestingly, it was not altered until 1966. The mid-1960s is significant for it was the time when a series of regulations were introduced in an attempt to control the social predicaments of rapid postwar urbanization. Similar to other parts of the developing world, Turkish metropolises began to experience massive rural to urban migration after the 1950s. The major cities were quickly surrounded with squatter settlements built illegally on public land. The increasing population transformed the overall morphology of the cities as well as their social structures. These transformations were tackled with a series of legal instruments introduced in the 1960s. Two of the most important ones were the Flat Ownership Act (1965) and the Gecekondu (Turkish term used for squatter houses) Act (1966).

The Flat Ownership Act was critical in the regeneration of city centers since construction costs did not allow individual landowners to undertake the renewal of their lots despite regulations increasing building heights. This required the organization of the market by small contractors who would then need to sell individual apartments to different buyers (Öncü, 1988). Thus, the Act triggered the transformation of the old mahalle with apartment buildings inhabited by diverse users. The Gecekondu Act, on the other hand, was instated to legalize existing squatter settlements and preventing new ones to be built. Although it wouldn't be successful in gecekondu prevention, it was important for the recognition of this urban phenomenon rather than denying its existence. Hence, the new law reorganizing the bekçi should be understood as a component of these regulations trying to cope with the new urban condition. Now, they were further formalized with uniforms, handguns, and salaries provided by the Ministry of Interior. The squatter neighborhoods were seen as a threat to the urban order that required close monitoring of the central state and not the municipality, especially since the mid-1960s witnessed the rise of social movements across the country. Within this perspective, the bekçi were expected to extend the reach of the police force into the peripheries. But the new act also indicated that they were still responsible for the well-being of the citizens in the neighborhood and monitoring morality and decency in the mahalle. Thus, although the merger of residential and central quarters of the city were similarly defined as the domains of bekçi, their primary territory was mahalle.

The 1980s witnessed a shift in urbanization policies in Turkey under the influence of three major dynamics; namely, the reorganization of the municipal structure (introducing metropolitan municipalities), gecekond $u$ amnesties allowing the transformation of single-story huts into 4-5 story apartment buildings, and the establishment of Mass Housing Administration providing loans for middle-class cooperatives that would play role in suburban sprawl (Buğra, 1998; Işık \& 
Pınarcioğlu, 2001). This was the end of the city of squatters and social movements. Thus, the bekçi gradually became obsolete in the late 1980s, with the expanded and technologically equipped police force, and the rise of surveillance technologies. In early 1990s, it was decided not to employ any new bekçi and to pull the existing ones out of the streets. The number of the bekçi dropped from 21,000 in 1991 to 3,100 in 2015 (Aksungur, 2018, p. 122). Yet in 2017, the Ministry of Interior revitalized the bekçi, nicknaming them "night hawks," with 700 new recruits in Istanbul. This was followed by 7,000 in 2017 and 10,000 more in 2018 (Haberturk, 2018). We argue that the reemergence of the bekçi as a branch of the police force is related to the contemporary urban condition of Turkish metropolises; but it is also related to the political power struggles in the country and, by extension, the police force.

\section{The Revival of the Bekçi}

The republican history of Turkey was marked by radical secularism strictly controlling the public representations of Islam. It was only in 2002 after a severe economic crisis that an Islamist party (the Justice and Development Party [JDP]) came to power. The early years of the JDP in power was a fierce struggle against the secularist establishment spearheaded by the military. In its quest for power, the JDP allied with different political actors ranging from liberals to nationalists, depending on the immediate needs of the conjuncture. However, religious groups provided constant support to the Islamist government. Among these, the most significant was the Gülen movement, the largest among Turkish Islamist groups with international network and influences. ${ }^{2}$

Various interviewees indicated that the initial idea to reinstate the bekçi was related to the clash between the government and the Gülen movement. Accordingly, the Gülenist young generation of well-educated and technologically oriented bureaucrats was responsible for misusing their power to destabilize the government. The older generation displaced from the administrative posts argued for the human factor against technology, with the curious motto "the whistle is important." This meant that the whistle (incidentally the trademark of the bekçi more than the police) was a means of human connection and trust between the police and the citizens (Interviewee 4). The bekçi was almost the nostalgic cure for the internal crisis of the police.

Here, it is crucial to note that the misuse of surveillance technologies - particularly wiretapping - by the Gülenists was an outcome of the ongoing expansion of technological surveillance under the JDP. The party found at its disposal the new Central Population Administrative System (MERNIS), which was the product of the state's ongoing efforts to develop an efficient nationwide database (Topal, 2005). Significantly, even human rights reforms of the 2000s (a component of Turkey's accession process to the EU) has led to the increase of the disciplinary capacities of the state (Bahçecik, 2015). In the process, criminal justice processes based on technological evidence replaced testimonies, which was affirmed as contributing to the elimination of torture. However, in the absence of a proper legal framework for their use, new technological instruments were easily utilized by the JDP against its opponents (Topak, 2017).

With the escalation of tension with the Gülenist fraction within the bureaucracy, the government worked hard to clear them out and reestablish its authority. These efforts weakened the security forces in quantity. Especially with the mass purges in the wake of the failed coup in 2016, the number of expelled police officers reached drastic levels. About 100,000 new officers were recruited between 2014 and 2018 (Interviewee 5). Within this context, the bekçi was first thought as a quantitative (and hasty) response to the sudden shrink in numbers.

It was implemented as an undertaking of the General Directorate of Security, leaving the Academy aside (which was also being reorganized in order to eradicate Gülenist influence) (Interviewee 4). The provincial police departments under the governorships were authorized to conduct exams; the recruits were to receive a much shorter training (6 to 8 weeks) with a condensed version of the police curriculum and they would be deployed in their hometowns. Even 
the regulations dated back to 1966 and defining the requirement for education at elementary level were not revised (Akşam, 2018). We expect that this condition will change soon as all our interviewees think that new conditions require a better-educated security force. ${ }^{3}$ However, the selection system was not satisfactory in all provinces, and eventually the recruitment process was transferred to the Academy. An exam system and a new curriculum has been designed recently (Interviewee 5).

Here, it is also necessary to consider the demand side of bekçi recruitment. According to Interviewee 5, applicants consider being a bekçi in order to secure a job under current economic circumstances, and they may not keep this position too long. Almost one-fourth of applicants being university graduates supports this claim (Diken, 2017).

\section{Situating the Bekçi in Contemporary Urban Context}

As we have shown, the revival of the bekçi is still in the process of organization. They are formally positioned in the district departments, which assign them temporarily to police stations. This is in stark contrast to the old model where the bekçi was attached to the mahalle via the local police station. We will return to the spatial predicaments of this diversion that makes their exact position (physical location as well as hierarchical standing) ambiguous. Moreover, the Minister of Interior is determined to deploy the bekçi in his "war on drugs" (Cumhuriyet, 2018). Despite the confusion regarding the new role of bekçi with respect to the law enforcement, it is possible to detect tendencies, which are related to the current urban condition in Turkish metropolises.

The first decade under the JDP witnessed an economic expansion that primarily depended on urban investments such as the gentrification of old squatter areas, the revitalization of city centers, growing numbers of shopping malls, and the construction of new roads promoting the increase of vehicular traffic. However, these projects were proposed and rapidly implemented without any deliberation; a trademark method defined as "authoritarian populism of the entrepreneurial state" (Eraydin, 2012).

The negative impact of such regeneration projects went hand in hand with the imposition of Islamic codes in the cultural domain such as the reorganization of primary school curricula along Islamic teachings, attempts to ban abortion, and the introduction of strict limitations on the consumption of alcohol in public spaces (Kaya, 2015). Under these conditions, a small environmentalist protest against the destruction of a particular urban commons - the Gezi Park in Istanbul — quickly turned into a spectacular nation-wide rebellion in June 2013 (Batuman, 2015). In a few days, millions took to the streets to demonstrate against the JDP government. The government responded harshly, and the repression of the protests rapidly extended to the institutionalization of state oppression with new legislation. This would escalate after the leaked tapes by the end of the same year and finally took the form of "state of emergency" in the wake of the failed coup in 2016.

What is important for our discussion is the new urban condition, which found its political expression in the Gezi protests. The JDP sought to further urbanize the country as soon as it assumed power. It reduced agricultural subsidies and opened the sector to foreign competition (Günaydın, 2009). In addition, the government reorganized administrative units to further diminish the rural territories. In 2002, urban population in Turkey was $65 \%$; more than half of this lived in areas controlled by the 16 metropolitan municipalities. Through successive reforms, 55\% of the national territory inhabited by $76 \%$ of the population was defined as metropolitan areas by 2012 (Arıkboğa, 2013; Zengin 2014).

This transformation was not merely quantitative. Its direct impact on urban politics was the disparately increased weight of semi-urban peripheries, which traditionally vote conservative in Turkey despite the economic deprivation in agriculture. Moreover, another outcome of this transformation was related to the micro scale organization of the urban society: 16,500 rural units 
(villages) were transformed into metropolitan mahalles. This was not merely the expansion of municipal administration to the peripheries; the definition of the urban was changing with increasing influence of the periphery in urban politics (Batuman, 2018, p. 110).

The urbanization process under the JDP had two significant aspects. The first one is the expanding primacy of the urban across the country albeit in a hybrid form integrating various-sized communities. The second one is the inherent politicization of this process as witnessed by the Gezi protests. Therefore, the post-Gezi Turkish metropolis contains two urban forces: the (conservative) pressure of the periphery on the center (represented best via the local power structure in the municipal assemblies) and the increased potential of political dissent (latent in the public space). The bekçi is the urban form that represents the deployment of the former to control the latter.

The new urban condition also displays significant difference in terms of the regime of visibility in public space. As we have indicated earlier, the threat posed by the squatters to the urban order was intended to be contained in these neighborhoods and kept invisible in public space. Under these conditions, the only "legitimate" form of appearance in public space was political action. The squatters could only become visible by becoming a part of mass political movement. Yet, with the dissolution of this urban configuration - gated communities in the peripheries, renewal of gecekondu zones, and the increased mobility in the cities - the control of visibility in public space has also changed drastically, which we will discuss below.

\section{From Mahalle to the Public Space: The Appearance of Bekçi}

Today, mahalle simultaneously refers to an existing urban social realm and an idealized cultural milieu marked by harmony, face-to-face relations, and sense of community. In this respect, it can represent an ideal image of housing environment. Appropriately, mahalle was the first architectural image used for the advertisement of gated communities in Turkey (Özaslan, Akalın \& Wilson, 2011). It was idealized as the space of neighborliness and sense of community. Mahalle as a representation is also utilized for the promotion of recent urban renewal projects, particularly in cases where Istanbul's run-down historical quarters are gentrified. The projects produced for these areas claim to get inspirations from the traditional Ottoman mahalle (Bozdoğan \& Akcan, 2012, pp. 290-91; Çavuşoğlu \& Strutz, 2014, pp. 138-39). In this sense, it represents the spatial image of the JDP's conservative worldview (Batuman, 2018, pp. 95-99).

The scale of housing in contemporary Turkish cities is defined as site, a cluster of high-rise blocks minimizing socialization among neighbors. ${ }^{4}$ While these compounds are not necessarily gated communities with security personnel, they all have walls or fences marking their borders. That is, the contemporary mahalle, rather than being characterized by face-to-face neighborly relations, is often an accumulation of sites.

If we look at the spatial configuration of law enforcement, we see that the police stations are structured in a highly territorial manner. Interviewee 4 indicated that the station is identified with the map of its territory; it is "the first thing that one sees upon entering the station" and both the map and the borders it represents are perceived as "sacred." Yet the morphology of the actual mahalle comprising housing compounds creates a hollowed-out map. When they patrol the streets of the residential quarters, the bekçi do not enter the compounds, which significantly reduces their spatial reach. As a result, the capacity of the new bekçi in preventing burglary is considerably diminished. In return, they turn to the public practices of the residents. ${ }^{5}$ Close surveillance in the neighborhood intrudes in the lives of people who have beliefs and behaviors outside the dominant social norms. Several complaints from retailers selling alcoholic beverages and their customers who were intimidated by bekçi after 10 PM indicate such a tendency (Öztürk, 2018).

In our interviews, several of our informants argued the prevalence of the mahalle as a social unit, and they claimed that the bekçi would be assigned to a police station and would then patrol the streets of a particular mahalle to recreate face-to-face contact with locals in a friendly 
relationship. Their appointment to their hometowns is an attempt to support these contacts. If and how this could be possible in contemporary Turkish cities, especially major ones such as Istanbul and Ankara with populations of 15 and 5 million, respectively, remains unanswered. Currently, there are more than 20 cities with a population exceeding one million.

If we look at the operation guidelines of the new bekçi, we see that the old definition of patrolling both mahalle and marketplace - that is, the public spaces downtown - is intact. Yet, there is a significant difference now. While this unification represented the extension of the authority of the security forces into the squatter neighborhoods in the peripheries, now it serves the exact opposite. It is now the deployment of an element that belonged to the mahalle - the residential periphery - to the center. This is not only about the physical space of the mahalle but also about its conservative cultural implications, which is visible in the statements of the government officials. For instance, speaking on the new bekçi policy at a ceremony, Minister of Interior Süleyman Soylu announced that the plan was to have 20,000 bekçi patrolling "every corner of Turkey and particularly the big cities" (Milliyet, 2017). He declared that the idea was to deploy the bekçi, which is a part of "our traditions and customs" and a figure that "our streets are accustomed to." At the end of the ceremony he presented a bekçi hat and a whistle to President Erdoğan, who blew it joyfully (Milliyet, 2017).

As we have stated earlier, public space is marked by the dialectic of visibility and appearance, where the citizen is simultaneously visible to the gaze of power and their appearance is a political claim. This is closely related to what Lefebvre calls "right to the city." According to him, the right to the city implies the right "to freedom, to individualization and socialization . . . to participation and appropriation," which also includes "the right to the use of the [city] center," which he views as "a privileged place" (Lefebvre, 1996, p. 147). This privileged place is the space of difference, exchange, communication, and anonymity. It is crucial to note that, the definition of "right to the city" has transformed parallel to the changing modality of urbanization in Turkey. As we have argued earlier, the squatters' demand to be recognized by the urban order had become obsolete with the legalization and commodification of their homes via amnesties in the 1980s. Moreover, the increased wealth and prosperity in the globalized metropolises of consumerism has produced new generations with radically different desires and expectations. In this respect, the issue at stake in contemporary Turkish cities is less an issue of (private) lifestyles and rather a new type of right to the city in the form of appropriation of (public) urban life. This distinction has presented itself in the form of open rebellion in the Gezi protests rejecting state control of public space and the definition of practices in it. Moreover, the new urban condition has also produced a new regime of visibility with the intertwined use of visual technologies by the state and urbanites, sudden emergence of flash-mob actions, etc. (Molnar, 2014).

The old bekçi, in this context, is a part of the nostalgic/conservative image of the mahalle (Cimrin, 2017). In this regard, the relocation of the bekçi in public space is closely related to what Atkinson (2003, p. 1841) has defined as "security through domestication": residential desires for safety and homogeneity are imposed on public spaces. This tendency rules out politics: interaction among citizens that produce public space is perceived as potential discord and "gathering" as a threat to the authority that governs bodies.

The introduction - or rather appearance - of the bekçi in the public spaces of the city center invokes anxiety. In the public space, the police may conduct routine and random searches, which would be perceived as normal by the citizens. But the interference of the bekçi is different. He belongs to the static territory of the neighborhood; incidentally, the word bekçi is literally derived from the Turkish word for "waiting" (in the sense of guarding). So, whomever he stops and searches (in the mahalle) is either an alien or a commoner involved in an improper activity.

The search conducted by the mobile bekçi patrolling the public space is different than that of the police who usually do it by stationing at a particular spot. The urbanites walk through police control, while bekçi moves toward the person he will search. That is why being the object of 
investigation by the bekçi implies suspicion more than that of the police. The bekçi is not a figure of anonymity, and his approach (rather than gaze) triggers anxiety. Here, we need to differentiate the forms of visibility operating through the security checks performed by the police and the bekçi. The former embodies "random visibility" addressing the citizen temporarily. This necessitates the citizen's acknowledgment of the police (and state power by extension) but the knowledge that the process is random quickly renders the citizen "invisible" right after the encounter. The security check conducted by the bekçi, in contrast, embodies "targeted visibility." The choice of the person to be checked and searched puts a mark on her; she remains visible to the crowd as a potential suspect even after the encounter with the security forces end.

Interestingly, the anxiety that the bekçi triggers works both ways. The incident we reported at the beginning of the article is illustrative of this. Our interviewees have indicated that the security forces (be it police officers or bekçi) should explain to the citizens that their choice of whom to stop and search is random. Yet, randomness does not exclude biases and insecurity. The interviewees with experience in the field also indicated (somewhat proudly) that an experienced officer would know from the looks of a person whether he/she is a potential suspect. This is indeed an act of profiling. And here, the human factor - in comparison to high-tech surveillance systems-becomes critical in affirming profiling as the implicit definition of "suspicious subjects" (KaosGL, 2018; Sol, 2019; T24, 2018).

But there is more to the case of bekçi. In the first days of bekçi revival, many citizens - not very surprisingly, mostly male - questioned their authority and this is one of the weakest spots of government officials. This made newly assigned bekçi insecure and they demanded better public presentation (sgkrehberi, 2018). The insecurity of the security personnel is a curious topic. Especially in settlements with lower rates of crime, the police feel vulnerable, useless, and undesired (Koca, 2013). They become the object of scrutiny under the gazes of distrusting citizens. This is very much the case with the new bekçi especially with their image: conceived as young and virile but perceived by the public as inexperienced and impotent. This is why the governor of Samsun demanded citizens to show respect to the bekçi (Hürriyet, 2018).

Our informants explained the expected contribution of revival of bekçi as controlling crowded streets instead of silent and unobserved ones, claiming that the potential of crime is higher when there is a crowd. This definition blurs the distinction between the residential quarters and public spaces. In fact, an interesting finding of our research is the disparity of the very notion of public space as understood by the police and the academics. ${ }^{6}$ Within police terminology "public space" refers to public buildings and they use the term "open space" for streets, plazas and the like. This definition - almost unconsciously - flattens the differences embodied in public spaces and wipes out the political connotations of public space. Hence, the public square in the center of a major city is perceived as similar to a street in a residential quarter. The treatment of crime - or its prevention - is also similar. Rather than the old bekçi "waiting" in the neighborhood, guaranteeing its quiet, the new bekçi is strikingly mobile; they are transported to "hot spots" where there is crowd (hence risk of crime) for short shifts (of two hours), then taken back to the station to rest before another shift in another location (Interviewee 5).

This way of defining crime immediately changes its scope and content. While one expects bekçi to be involved in petty crimes of theft and burglary, crime in this context involves terrorist acts and political protests. In other words, gatherings on the street might lead to actions of political nature. Crowded avenues, traffic junctions and subway entrances/exits, and school districts are defined as "sensitive areas," with potential for crime (Interviewee 3). Drug dealing, prostitution, and vandalism constitute remaining targets of night watch and surveillance. All our informants mentioned the impact of visibility of the police as a means to prevent crime. In that respect, there seems to be a consensus on the idea of patrolling security forces - in our case, bekçi — among various governing bodies. ${ }^{7}$

In other words, the tasks of the new bekçi do not have much in common with the old ones; protecting the neighborhood from the intrusion of strangers and preventing petty crime seem to 
be outmoded. They work in pairs, not alone as the old ones. Besides, in all interviews, increasing and competent use of technology was mentioned proudly, which indicates the inevitable penetration of modernity into state surveillance. The interaction between different units of security forces is also pointed out more than once. Their spatial allocation is not strict, and telecommunication and surveillance devices further increase flexibility. One informant described their role as inhibiting potential crime with their visual presence (Interviewee 2).

The appearance of the new bekçi is also worth discussion in terms of the image they present. They are expected to look "young, educated and fit," and these qualities are expected to make them more approachable for young people (Interviewee 5). Our interviewee suggests as an example that the new bekçi now nicely warns young people drinking and shouting in the parks at nights, as a result of mutual sympathy due to age similarity. It seems that the appearance of the $b e k c ̧ i$ in public space involves both their presence and their image: the looks of the new bekçi is supposed to create respect via admiration (rather than fear). Surely, this optimistic evaluation of the young bekçi patrolling streets overlooks potential resentments among and prejudices against youth from different social backgrounds.

Considering prejudices against certain groups of citizens, news so far indicates that LBGT and sex workers are main targets of security personnel. Here it is crucial to note that neither their curriculum nor their training instructs the bekçi to impose conservative values. ${ }^{8}$ Yet the backgrounds of the recruits (usually from low-income traditional/ conservative families) are almost always alien - if not hostile - to the cosmopolitanism of the public space. Moreover, all our interviewees emphasized that law enforcement is an occupation "learned mainly through practice as an apprentice." This means the reproduction of prejudices through the passing of tacit knowledge (Interviewee 4). As we have discussed, the insecurity of the bekçi also further fuels the tension between the confident middle-class youth enjoying the public space and the bekçi demanding recognition.

\section{Conclusion}

Although the aim of reinstating the bekçi is defined as "protecting the public" and removing improper behavior out of streets, "improving the aesthetics of public space" is an important (and typical) aspect of their intervention (Cook \& Whowell, 2011). Cleansing the streets from such unwanted elements necessitates their invisibility (Lippert and Walby, 2013). It is interesting that our informants see profiling as a positive aspect of surveillance and bragged about being competent to notice a potential crime when they see a suspicious person-or even a car. This is an obvious invasion of privacy rights of citizens (Veliz, 2019). The strong tradition of mentoring in all levels of law enforcement results in the transfer of profiling as know-how between generations. It is not unexpected to transfer prejudices related to gender, belief, attitude, and class in addition to political views. Generally raised in lower and lower-middle class families and earning a low salary, the bekçi's — no more than 25 years when they are first recruited — attitude towards better educated and more affluent youth may be biased.

The revival of the bekçi is an ongoing process. So it is early to verify our assumptions and derive definitive conclusions. Nevertheless, it is possible to identify strong tendencies in the operation of the bekçi. On one hand, the Turkish historical and cultural context indicates pervasiveness of authority, conservatism, and patriarchy. This is further fueled by recent internal and external political incidents. The clash within security bureaucracy and the elimination of the Gülenist faction and the Gezi protests prompted securitization. The bekçi emerged here as an instrument unifying the two trends of conservatism and securitization. It is also worth mentioning how technology is also an indispensable component of the new bekçi.

We have argued that it is crucial to situate the bekçi within the changing urban context. Its mid-twentieth-century deployment represented the state's attempt at controlling the urban condition produced by postwar urbanization and the growing social movements in the 1960 s. While 
this mode of urbanism seemed to be outmoded by the 1980s, we argued that the reinstatement of the bekçi is very much related to the current urban condition, which, this time, presents a new hybrid form marked by the conservative pressure of the (newly urbanized) peripheries on the urban centers. The bekçi represents the extension of a (conservative) social control mechanism that belonged to the residential neighborhood to the city centers. Nevertheless, it would be a mistake to see the re-installation of the bekçi as an illustration of the JDP's "inherent" conservatism. It is rather a response to the politicization of public space in contemporary Turkish cities. ${ }^{9}$

The new bekçi operates differently than its predecessors in terms of spatial deployment, mobility, and use of technology. It would be worth reflecting on the spatial character of bekçi revival and further analyze how districts allocate bekçi in specific neighborhoods, how this is related to the crime maps of districts and how specific criteria are used to define "sensitive areas" in relation to public spaces. Nevertheless, the strategies bekçi transfers from the residential neighborhood to the regime of visibility in public space is much more effective in social control. In contrast to the impersonal style of the police, the bekçi's involvement in public space is more personal. It operates through "targeted visibility" rather than "random visibility," and produces a distinctive regime of control comprising the visibility of the watchmen (carrying a set of historically accumulated connotations), that of the ordinary citizens as well as the "undesirable" ones. Albeit in an imperfect form, the bekçi seems to have redeployed this seemingly obsolete form of security measure in an effective way in the public spaces of Turkish metropolises.

\section{Declaration of Conflicting Interests}

The author(s) declared no potential conflicts of interest with respect to the research, authorship, and/or publication of this article.

\section{Funding}

The author(s) received no financial support for the research, authorship, and/or publication of this article.

\section{ORCID iD}

Bülent Batuman (D) https://orcid.org/0000-0003-4921-3261

\section{Notes}

1. In order to keep the interviewees anonymous, we labeled them with numbers instead of using their names. Interviewee 1, high-ranking administrator, General Directorate of Security (October 22, 2018); Interviewee 2, high-ranking administrator, General Directorate of Security (October 22, 2018); Interviewee 3 high-ranking administrator, Ankara Province Police Department (October 31, 2018); Interviewee 4, retired member of the Police Academy (October 31, 2018); Interviewee 5, member of the Police Academy (December 28, 2018).

2. Unlike other Islamic groups, the Gülen movement saw itself an equal partner of the JDP since it provided well-educated cadres, which were vital to take over the bureaucracy (Özdalga, 2000; Turam, 2007; Hendrick, 2013). The cooperation between the two parties turned into a deadly clash after 2013 and led to a failed military coup on July 15, 2016, in which Gülenist officers played an important role. The first open clash was the leaking of tapes implying corruption among the members of the cabinet in December 2013. The tapes were leaked by Gülen's supporters within the police force. Hence, this was a traumatic event for the security bureaucracy.

3. In the recruitment process, a high-school diploma is listed as requirement.

4. The dominance of this scale was affirmed with an amendment to the Flat Ownership Act (which originally addressed the single apartment building with multiple flats built in one lot) in 1983, recognizing the increasing number of sites containing multiple blocks in single lots.

5. Interviewee 4 predicted that in the absence of the cultural sphere of the old mahalle, "the bekçi will inevitably tend to behave like the police." 
6. See Houssay-Holzschuch (2016) for a discussion on the ambiguity of public space.

7. For cases of European countries, see Cook and Whowell (2011).

8. When we examine recruitment exams, we observe that they do not reflect a choice of conservative recruits; however, candidates are asked questions of political content and expected to have mainstream views (particular attention is given to Gülenist connections and affiliation with Kurdish separatism or left-wing militancy) (Interviewee 5).

9. In an interesting parallel, the rise of the nostalgic image of the mahalle under the JDP has only occurred in the wake of the Gezi protests. Neither was this a policy born out of JDP's conservatism; it was a contingent response to the political conditions (Batuman, 2018, pp. 98-99).

\section{References}

Akşam. (2018). Bekçi alım başvuru şartları nedir EGM Bekçi mülakat yazılı sınav soruları neler çıkıyor örnek sorular. Akşam, November 9. Retrieved from https://www.aksam.com.tr/yasam/egm-bekcimulakat-yazili-sinav-sorulari-neler-cikiyor-ornek-sorular-bekci-alim-basvuru-sartlari/haber-790743

Aksungur, A. B. (2018). Türk İdare geleneğinde yerel Güvenlik: Mahalle bekçilerine dair bir inceleme (unpublished master's thesis), Konya: Selçuk University.

Arendt, H. (1998). The human condition, Chicago, IL: The University of Chicago Press. (Originally published in 1958).

Arıkboğa, E. (2013). Geçmişten geleceğe büyükşehir belediye modeli. Yerel Politikalar, 3, 48-96.

Atkinson, R. (2003). Domestication by cappuccino or a revenge on urban space? Control and empowerment in the management of public spaces. Urban Studies, 40(9), 1829-1843.

Bahçecik, Ş. O. (2015). The power effects of human rights reforms in Turkey: Enhanced surveillance and depoliticization. Third World Quarterly, 36(6), 1222-1236.

Batuman, B. (2015). "Everywhere is Taksim": The politics of public space from nation-building to neoliberal Islamism and beyond. Journal of Urban History, 41(5), 881-907.

Batuman, B. (2018). New Islamist architecture and urbanism: Negotiating nation and Islam through built environment in Turkey. Abingdon and New York: Routledge.

Boyar, E., \& Fleet, K. (2010). A social history of Ottoman Istanbul, Cambridge: Cambridge University Press.

Bozdoğan, S., \& Akcan, E. (2012). Turkey: Modern architectures in history, London: Reaktion Books.

Buğra, A. (1998). The immoral economy of housing in Turkey. International Journal of Urban and Regional Research, 22(2), 303-307.

Çavuşoğlu, E., \& Strutz, J. (2014) Producing force and consent: Urban transformation and corporatism in Turkey, City 18 (2), 134-148.

Charlesworth, S. J. (2009). The space of appearances: The constitution of the public realm. Space and Culture, 12(2), 263-281.

Cimrin, H. (2017, December 11). Bekçi Amca geri mi dönüyor? Retrieved from https://www.sabah.com.tr/ akdeniz/2017/12/11/bekci-amca-geri-mi-donuyor

Cook, I.R., \& Whowell, M. (2011). Visibility and the policing of public space. Geography Compass, 5(8), 610-622.

Cumhuriyet. (2018). Süleyman Soylu: Benim polisim, jandarmam ne demek istediğimi anladı Cumhuriyet, January 5. Retrieved from http://www.cumhuriyet.com.tr/haber/siyaset/899156/Suleyman_Soylu_ Benim_polisim_jandarmam_ne_demek_istedigimi_anladi.html

de Backer, M. (2018, May). Regimes of Visibility: Hanging Out in Brussels' Public Spaces. Space and Culture. https://doi.org/10.1177/1206331218773292

Diken. (2017). Bekçiliğe 9 bin 980 başvuru: 2 bin 327'si üniversite mezunu, sekizi yüksek lisanslı. Diken, December 6. Retrieved from http://www.diken.com.tr/bekcilige-9-bin-980-basvuru-2-bin-327si-universite-mezunu-sekizi-yuksek-lisansli/

Eraydın, A. (2012). Girişimci devlet, otoriterleşen populizm: Neoliberalizmin yeni evresinde devletin yeni davranış kalıpları. Third Symposium of Urban and Regional Investigations Network, 13-34.

Foucault, M. (1995. [1977]). Discipline \& punish: The birth of the prison (A. Sheridan, Trans.). New York: Vintage Books. (Originally published in 1977.)

Fussy, P., \& Coaffee, J. (2012). Urban spaces of surveillance. In K. Ball, K. D. Haggerty \& D. Lyon (Eds.), Routledge handbook of surveillance studies, (pp. 201-208). London and New York: Routledge. 
Günaydın, G. (2009). Türkiye tarım politikalarında “yapısal uyum”: 2000'li yıllar. Mülkiye, 33(1), $175-222$.

Haberturk. (2018). 7 bin bekçi alımı için ön başvuru başladı. Haberturk, June 8. Retrieved from https:// www.haberturk.com/ankarahaberleri/15618258-7-bin-bekci-alimi-icin-on-basvuru-basladi

Hendrick, J. D. (2013). Gülen: The ambiguous politics of market Islam in Turkey and the world. New York and London: New York University Press.

Houssay-Holzschuch, M. (2016). What to do with public space. In M. De Backer, L. Melgaço, G. Varna \& F. Menichelli (Eds.), Order and conflict in public space, (216-220). New York: Routledge.

Hürriyet. (2018). Emniyet Müdürü Yavuz: Bekçilere sayg1 duyulması gerekir. Hürriyet, October 22. Retrieved from http://www.hurriyet.com.tr/yerel-haberler/samsun/emniyet-muduru-yavuz-bekcileresaygi-duyulmasi-40994967

Işık, O., \& Pınarcioğlu, M. (2001). Nöbetleşe yoksulluk, Istanbul: İletişim.

KaosGL. (2018). Ankara'da bekçilerden trans kadınlara "sokağa çıkma yasağı!" KaosGL, September 13. Retrieved from http://kaosgl.org/sayfa.php?id=26561

Karpat, K. H. (2002). Millets and nationality: The roots of the incongruity of nation and state in the postOttoman era. In Karpat Kemal (Ed.), Studies on Ottoman social and political history: Selected articles and essays (pp. 611-675), Leiden, Boston, MA and Köln: Brill.

Kaya, A. (2015). Islamization of Turkey under the AKP rule: Empowering family, faith and charity. South European Society and Politics, 20(1), 47-69.

Koca, E. (2013). "Sucsuz yere polislik": Artvin'de polis-halk ilişkisi uzerine etnografik bir inceleme. Amme İdaresi Dergisi, 46(4), 157-184.

Koskela, H. (2004). Webcams, TV shows and mobile phones: Empowering exhibitionism. Surveillance \& Society, 2(2/3), 199-215.

Lefebvre, H. (1996). Writings on cities, Oxford: Blackwell.

Leman-Langlois, S. (2019). Technologies of surveillance. In M. Deflem (Ed.), The handbook of social control (pp. 349-360), Oxford: Wiley Blackwell.

Levy, N. (2008). Yakından korunan düzen: Abdülhamid devrinden ikinci meşrutiyet dönemine bekçi orneği. In Benlisoy (Ed.), Osmanlı'da asayiş, suç ve ceza, (pp. F. 135-144), Istanbul: Tarih Vakfi Yurt Yayınları.

Lippert, R. K., \& Walby, K. (Eds) (2013). Policing cities: Urban securitization and regulation in a 21st century world. New York: Routledge.

Lyon, D. (2007). Surveillance studies: An overview. Cambridge: Polity Press.

Milliyet. (2017) Bakan Soylu: "7 bin 500 bekçi daha ihdas edildi." Milliyet, August 25. Retrieved from http://www.milliyet.com.tr/bakan-soylu-7-bin-500-bekci-daha-siyaset-2508690/

Molnár, V. (2014). Reframing public space through digital mobilization: Flash mobs and contemporary urban youth culture. Space and Culture, 17(1), 43-58.

Newell, B. C. (2017). Collateral Visibility: A Socio-Legal Study of Police Body-Camera Adoption, Privacy, and Public Disclosure in Washington Square. Indiana Law Journal, 92(4), 1329-1399.

Öncü, A. (1988). The Politics of the Urban Land Market in Turkey: 1950-1980. International Journal of Urban and Regional Research, 12(1), 38-64.

Özaslan, N., Akalın, A., \& Wilson, C. (2011). Postmodernism and Consumer Culture: Image-Production Via Residential Architecture in Post-1980s Turkey. African Journal of Business Management 5(7), 2597-2606.

Özdalga, E. (2000). Worldly Asceticism in Islamic Casting: Fethullah Gülen's Inspired Piety and Activism. Critique: Critical Middle Eastern Studies, 9(17), 83-104.

Öztürk, Y. (2018, August 21). Tekel esnafina şimdi de mahalle bekçisi tehdidi. Retrieved from https:// www.birgun.net/haber-detay/tekel-esnafina-simdi-de-mahalle-bekcisi-tehdidi-228331.html

Sgkrehberi. (2018). Bekçilerin kimlik bunalımı! sgkrehberi, August 26. Retrieved from https://www.sgkrehberi.com/haber/172407/bekcilerin-kimlik-bunalimi.html

Sol. (2019). Bekçiler trans kadına saldırdı, zorla karakola götürdü. Sol, January 13. Retrieved from http:// haber.sol.org.tr/turkiye/bekciler-trans-kadina-saldirdi-zorla-karakola-goturdu-254663

T24. (2018). Trans kadınlar, 'bekçi şiddeti’ne karşı bir araya geldi. T24, October 5. Retrieved from https:// t24.com.tr/haber/trans-kadinlar-bekci-siddetine-karsi-bir-araya-geldi,716518

Timan, T., \& Albrechtslund, A. (2018). Surveillance, Self and Smartphones: Tracking Practices in the Nightlife. Science and Engineering Ethics, 24(3), 853-870. 
Topak, Ö, E. (2017). The Making of a Totalitarian Surveillance Machine: Surveillance in Turkey Under AKP Rule. Surveillance \& Society, 15(3/4), 535-542.

Topal, C. (2005). Global Citizens and Local Powers: Surveillance in Turkey. Social Text, 23(2), 85-93.

Tulumello, S. (2015). From 'Spaces of Fear' to 'Fearscapes': Mapping for Reframing Theories about the Spatialization of Fear in Urban Space. Space and Culture, 18(3), 257-272.

Turam, B. (2007). Between Islam and the State: The Politics of Engagement. Stanford, CA: Stanford University Press.

Véliz, C. (2019). In the privacy of our streets. In B. C. Newell, T. Timan \& B. Koops (Eds.), Surveillance, Privacy and Public Space (pp. 16-32). Oxon and New York: Routledge.

Webb, M. (2007). Illusions of Security: Global Surveillance and Democracy in the post-9/11 World. San Francisco: City Lights.

Zengin, O. (2014). Büyükşehir Belediyesi Sisteminin Dönüşümü: Son On Yılın Değerlendirmesi. Ankara Barosu Dergisi, 72(2), 91-116.

\section{Author Biographies}

Bülent Batuman is Associate Professor of Architecture at Bilkent University with joint appointment in the Department of Urban Design and Landscape Architecture and Department of Architecture. He studied at the Middle East Technical University and received his PhD in History and Theory of Art and Architecture from State University of New York-Binghamton. His research areas include social production and politics of built environment, history and theory of modern architecture and urbanism, and urban politics.

Feyzan Erkip is Professor in the Department of Urban Design and Landscape Architecture at Bilkent University. She received her PhD from the Department of City and Regional Planning at Middle East Technical University (METU). She is a member of the editorial board of Cities. She received URBANNET, Middle East Research Competition and TUBITAK research awards. Her research interests include urban transformations and consumption sites, leisure practices and spaces, environmental psychology and environmental design research. 